\title{
Library Cooperation and the Development of the North Carolina Information Network (NCIN): From the Great Depression Years to 1992
}

\author{
by Diane D. Kester and Plummer Alston Jones, Jr.
}

\begin{abstract}
$T$
he history of the development of library networks, computerization of library processes, and the uses of technology in libraries in North Carolina needs more attention. ${ }^{1}$ The acceptance of computerization and technology has been widespread, although many libraries feared that they would be left behind by the technological revolution. To the contrary, not only have North Carolina libraries and librarians worked cooperatively to keep up with technological advances throughout the various decades of the twentieth century since the Great Depression, but also they have been in the vanguard, often on the cutting edge, of the application of technology to librarianship. North Carolina librarians nearing retirement today arguably have seen greater changes in their profession and institutions than in any other time during the last five hundred years. Perhaps it is time to begin telling the story of this great transformation.
\end{abstract}

\section{Early Library Cooperation}

The earliest evidence of library cooperation in North Carolina is the cooperative effort of the academic libraries of the University of North Carolina and Duke University in the 1930s, with each institution accepting responsibility for acquisitions and collection development in specific subject areas. Evidence of public library cooperation occurred in 1941 when state aid was made available. In 1957, the University of North Carolina at Chapel Hill established the Interlibrary Service Center.

In 1964, as a result of the appointment of Governor Terry Sanford's Commission on Library Resources, a study of the libraries of North Carolina was undertaken. This Commission was charged "to make a comprehensive survey of all types of library resources in the state ... [and] to measure these resources against present and future needs, and come up with recommendations which can point out ways for all citizens and agencies to take steps toward meeting the state's growing and changing library needs." ${ }^{2}$

The resulting survey revealed the inadequacies of the state's libraries in terms of space, holdings, and librarians. Future demands for library services were seen as even greater. Recommendations of the survey were organized into ten distinct areas of library concerns: the State Library of North Carolina, the North Carolina Department of Archives and History, public libraries, university libraries, senior college libraries, junior college libraries, technical institutes and industrial education centers, school libraries, special libraries, and library education. Opportunities for expansion of library cooperation ran throughout 
these recommendations, including the need for a more complete union catalog of holdings of North Carolina state agencies and public libraries; expansion of the State Processing Center at the State Library of North Carolina "to make its services available not only to public libraries, but to public schools, junior and community colleges, technical institutes, and industrial education centers"; extension of the well-established cooperative program in the Research Triangle and exploration of new areas of mutual interest; a cooperative program of centralized purchasing, cataloging, and processing for the junior college libraries; and encouragement to special libraries to cooperate with other types of scholarly and research libraries in the state. The need for staffing at school, administrative, and state levels was the emphasis for school library recommendations. ${ }^{3}$ In this same report, the Commission on Library Resources criticized the interlibrary loan program of the State Library by noting that the rules placed "restrictions on loans to high school, college, and correspondence or extension students and required identification of the borrower as a person with a 'serious' purpose." 4

Detailed descriptions of the types of libraries in North Carolina were made by the Commission, including extensive data on budgets, holdings, staffing, and facilities. The advantages of a central processing center were detailed. Of the public school systems, only Greensboro had centralized all acquisitions, cataloging, and preparation of materials. ${ }^{5}$ Consequently, the Commission recommended the "establishment of system-wide, perhaps better, regional processing centers to provide economically full technical processing services to all school administrative units." 6

In the chapter of the Commission's report on library cooperation, Jerrold Orne, University of North Carolina at Chapel Hill, alluded to the fact that North Carolina had been for several decades the pioneering leader among Southeastern states in this important area. "It takes no great stretch of imagination to visualize a national complex of libraries, each with intensively worked specialties, and each serving others for those fields and receiving in return similar services for others. The major lack is a central coordinating force capable of organizing the parts into a cohesive whole." 7

A conference on Interlibrary Cooperation in June 1967 was one of the first activities funded by the State Library under Title III of the Libraries Services and Construction Act (LSCA). This federal legislation provided grants for public library construction and multitype library cooperation. The conference brought together from different types of libraries in the state, "librarians who sought to identify their research, service, and communication needs and to establish needs jointly" and to consider needed changes in statewide interlibrary loan policies and procedures. There were three recommendations from the Title III Advisory Committee: (1) reevaluation and expansion of the North Carolina Union Catalog by adding holdings of community colleges and technical institutes and other libraries when their collections had special emphases; (2) exploration of additional interlibrary loan services to include dissertations, theses, and fiction; and (3) establishment of a systematic public relations program. ${ }^{8}$

In 1968, the State Board of Higher Education conducted a study of higher education programs, including a review of the libraries of the state's colleges and universities. One recommendation forthcoming from the report was that "a study be initiated as soon as possible to determine the feasibility of a central research library facility to serve the entire state." ${ }^{9}$ By this time, the State Library had assumed leadership in the development of a coordinated system of library service for the entire state. Funded by grants and LSCA Title III funds, the study was conducted by nationally recognized librarians, who concluded that "the time was ripe for the extension of the interlibrary services to all users throughout the state through the establishment of the North Carolina Libraries Services Network." 10 
There was ample evidence throughout the state of enthusiastic support of such a system by librarians. Interlibrary cooperation in North Carolina at that time included seven major projects: (1) the central processing center for colleges and technical institutes in the North Carolina Community College System; (2) the North Carolina Public Libraries Film Project and the processing of purchases for approximately 70 public libraries by the State Library of North Carolina; (3) formation of regional groupings of academic and public libraries to provide needed services; (4) manufacture of catalog cards on a contract basis for a number of major libraries by the University of North Carolina at Chapel Hill; (5) publication of the North Carolina Union Checklist of Scientific Serials and the formation of the Medical Library Extension Service, the latter linking the four major medical libraries in North Carolina and other libraries through the State Library in a service network to supply practicing physicians with reference material upon request; (6) cooperative reclassification of holdings to Library of Congress classification; and (7) sharing of facilities and equipment. ${ }^{11}$

The North Carolina Libraries Services Network came into being on August 13, 1970, when the State Library Board approved the concept of the network and announced its expansion as first priority for the 1971-73 biennium. ${ }^{12}$ The network was to link all the significant information resources and services in the state to improve service to the citizens of North Carolina. The usefulness of the increased access to knowledge would be not only to faculty and students at educational institutions, but also to those involved in developing the state's economy, and to others with specific individual or community concerns. ${ }^{13}$

Although both the State Board of Education and the State Board of Higher Education participated in discussion, they took no legislative action to support the network. Consequently the feasibility study group recommended that the General Assembly recognize and support (emphasis added) the North Carolina Libraries Services Network with the leadership of the State Library advised by a Network Advisory Committee. ${ }^{14}$

Few printed reference to activities of multitype library cooperation in North Carolina appear from 1971 until 1977. That year the General Assembly designated responsibility to the North Carolina Department of Cultural Resources (DCR) for coordinating cooperative programs among various types of libraries within the state and for coordinating state development with regional and national cooperative library programs. In response to the legislative mandate, the State Library's Ad Hoc Committee on Multitype Library Cooperation Committee was founded. David N. McKay, then State Librarian, formulated the following mission statement for the committee: "To provide the citizens of North Carolina with access to the state's total library and information resources within a cooperative framework which will support resource sharing and other cooperative programs among all types of libraries, thus improving library service generally." 15 Goals and objectives were established to build upon the current cooperation among the libraries of the state, to use developing technologies to link the libraries, and to enlist support of public officials and library users. ${ }^{16}$

The Networking Committee of the North Carolina Library Association and the Ad Hoc Committee on Multitype Library Cooperation compiled a status report of cooperative library activities in the 1970s. In 1981, this report was published as a Multitype Library Cooperation Working Paper No. 1, "Access to Information for North Carolinians." Statistics on college and university, community and junior college, public, school, and special libraries were compiled.

The committee recognized that the school libraries $(2,035$ at that 
time) held a large audiovisual collection; however, the number of total materials was insufficient "to meet the needs of student and teachers in all areas of the curriculum" and to allow "systematic resource sharing except among schools with a system." Also, the lack of telephones in many of the school library media centers seemed to indicate a lack of understanding on the part of the educational community with regard to even simple sharing of resources, such as computer time-sharing or using computers as a link to the local public library. This was not questioned at the time since school libraries were not members of the North Carolina Union Catalog and children were excluded from the North Carolina Interlibrary Loan Code. ${ }^{17}$

The committee also analyzed current cooperative library use in interlibrary loan statistics. This revealed the strength of libraries in the Piedmont area, but pointed out that the "growth of library and information resources in the Mountain and Coastal regions has not kept pace with the rate of population and industrial growth in these areas."18

At the time of the publication of this working paper, forty-eight local and statewide projects for resource sharing were identified, notably the North Carolina Union Catalog and the Interlibrary Services Network/InWATS (established in 1930), and the Triangle Research Libraries Network (TRLN) (established in 1979). The report concluded with a list of the major considerations that would have to be resolved in the development of a North Carolina Library Network:

- the need to convince librarians, users, and funding sources of the benefits of library cooperation and networking to general library service;

- the importance of creating individual machine-readable databases which would be compatible with accepted standards used by OCLC and other major bibliographic utilities so that the files could be combined either in a statewide catalog on microfiche (COM) or online catalog to replace eventually the North Carolina Union Catalog;

- encouragement of institutional responsibility for retrospective conversion projects, and the exploration of alternative supplemental funding sources for retrospective conversion of library holdings records;

- adequate maintenance of the North Carolina Union Catalog until such time as a statewide online or COM catalog was feasible;

- desirability of increased individual and cluster members in SOLINET/ OCLC;

- creation of a North Carolina Union List of Serials through the OCLC subsystem, financed cooperatively by participating institutions and LSCA, if feasible, and coordinated through State Library and the Ad Hoc Multitype Library Cooperation Committee;

- establishment of a technical committee to work toward coordination of automation activities, to serve as a clearing house for technical information, to develop plans for technical management of automated statewide database, and to monitor developments in the State Telecommunications Network;

- creation of a directory of automation projects and expertise in North Carolina for the purpose of sharing this expertise with libraries planning automation projects;

- future enhancement of areawide and multicounty resource sharing through a hierarchical system which would encourage sharing among neighboring libraries, including sharing of computer facilities, and which would include designation of area resource libraries with responsibility for coordination of multitype library resource 
sharing in their respective areas; and

- improved statewide access to audiovisual materials with consideration given to the contribution of expertise and resources which school libraries would be able to provide in coordinating sharing of these materials. ${ }^{19}$

In 1979 the Ad Hoc Committee on Multitype Library Cooperation merged with the NCLA Networking Committee to form the North Carolina Library Network Steering Committee. In 1981, the Technical Subcommittee was formed. Upon the recommendation of the newly organized committee, an outside firm, King Research, Inc., was contracted to study the feasibility of establishing a statewide library network in North Carolina. The contract also requested an investigation of governance, functions, and probable costs of hardware, software, and operations. Three purposes were stated as follows: (1) to assist the library community in arriving at a consensus on the functions, priorities, and structure of a statewide network; (2) to identify the potential benefits of a statewide library network as a basis for making recommendations to the Governor and to the General Assembly; and (3) to propose a realistic incremental plan of action, identifying steps to be taken prior to actual network structure and design. ${ }^{20}$

The King Research team initially identified tasks for study, including assessment of needs, evaluation of current services form SOLINET/OCLC, evaluation of technical requirements, and

ZOCs could be formed by libraries sharing a common geographic boundary, types of patrons, or special relationships among libraries or librarians. the development of feasible approaches. The team also presented a comparison of benefits and costs and recommendations for appropriate implementation steps. ${ }^{21}$

Public hearings were held across the state, in Charlotte, Asheville, Greensboro, and Greenville. Invitations were extended to librarians, patrons, friends and trustees, and local government officials to attend one of the public hearings held in February 1982. The final report of the King Research team, distributed in August 1982, included identification of current use of technology in the libraries in North Carolina and across the nation, causes of network failures, possible functions of a state network, and alternatives for library networking in the state. Throughout the report, local cooperative efforts were encouraged. Such local groups of libraries were designed as "ZOCs," or zones of convenience (later cooperation). ZOCs could be formed by libraries sharing a common geographic boundary, types of patrons, or special relationships among libraries or librarians.

The final report from King Research, Inc., included the following fourteen recommendations:

1. Networking activities should be directed towards, but not limited to, the continued building of a machine-readable bibliographic data base of statewide holdings.

2. The bibliographic database should be developed through the OCLC network either directly or indirectly.

3. The continued use of SOLINET (Southeastern Library Network) for the services it brokers for OCLC, with SOLINET activities and Board decisions being monitored carefully, or, if the situation should arise that SOLINET was unable to provide its traditional services, libraries in North Carolina should create their own network organization to act as intermediary between individual and groups of libraries and OCLC.

4. The primary OCLC services to be used should be cataloging and interlibrary loan, with those libraries currently using the services, or 
in the process of acquiring terminals, should continue to do so in the same way they were then operating, that is, on an individual basis, or through processing centers, or as consortia, and libraries not currently using OCLC should determine their mode of interaction according to the break-even points derived from cost analyses.

5. In addition to the cataloging of monographs, the OCLC system should be used to catalog serials and audiovisual materials, with union lists of serials to be produced using OCLC.

6. Directories of other statewide library resources (special collections, directories of expertise, etc.) should be produced centrally and updated on an annual basis, with data being collected using questionnaires (sent by mail).

7. Circulation records keeping was a function that should be organized at the local level using the circulation control module of an integrated library automation system, with each library or group of libraries (ZOC) eventually having an ILAS (integrated library automation system) to support an online public access catalog for members of the ZOC.

8. Acquisitions should be handled at the local level wherever possible through the establishment of ZOCs, using the acquisitions module of an ILAS to facilitate clerical procedures.

9. The placement of requests for interlibrary loan should be sequenced as follows: (a) a library should search its own ZOC online catalog; and, (b) if no catalog exists, or if the item was not located, the library should use the OCLC interlibrary loan subsystem.

10. A regionally organized statewide courier service, to cover a single ZOC or several, should be set up, with points of contact which would enable materials to pass across regional boundaries.

11. An individual within the State Library should be designated as the contact person to act as liaison between SOLINET, OCLC and other bibliographic utilities, and libraries within the state.

12. A pre-implementation period should be devoted to the promotion of networking activities in the state. This could be directed at all types of libraries or their staffs and should reassure both libraries and patrons about the effects of networking on their library environments and should gather their feedback and suggestions.

13. The Consultant for Multitype Library Cooperation or Assistant should be designated responsibility for providing advice to librarians throughout the state on the application of the cost models derived in this report, and on the interpretation of ensuing results.

14. A pilot project with approximately eight libraries should form a ZOC, design and implement the most appropriate system, and produce a set of guidelines for setting up ZOCs. ${ }^{22}$

King Research provided instruction on how pilot ZOCs could prepare a request for proposal. Online catalog services and circulation control were identified as high priority functions. Other functions that were suggested in a ZOC project were acquisitions, serials control, and management reports. Detailed cost analysis comparing manual and automated functions were provided.

In October 1982, the North Carolina Library Networking Steering Committee held its first meeting. Bylaws were adopted which included the composition of the steering committee from all types of libraries and library organizations. An organizational structure was approved. Seven task forces on various aspects of a statewide library network were established and charges were issued. The following mission statement was developed: to improve library and information service to the citizens of 
North Carolina by developing a comprehensive plan for multitype library cooperation. This plan, building upon the work of the State Library Ad Hoc Committee for Multitype Library Cooperation, the NCLA Networking Committee, and the King Research Study, would address not only the resources, services, products, and function of a statewide network, but would also address decision-making, management, and funding. The goal was to design a step-by-step blueprint for network development would include, but would not be limited to, building the statewide database, encouraging zones of cooperation (ZOCs), employing appropriate technology, improving document delivery, addressing continuing education needs, estimating funding requirements, and developing a public education program..$^{23}$

The seven task forces were Bibliographic Database, Document Delivery, Funding, Public Information, Library Education, Technology, and ZOCs. Each task force was given its charge, beginning with a response to recommendations of the King Research Report. The Steering Committee was given responsibility to evaluate findings and recommendations of the task forces, to establish priorities for action and a timeframe for implementation, and to make network policy recommendations for approval by the State Library Commission.

\section{Task Force on Bibliographic Database}

The first meeting of the Task Force on Bibliographic Database was on November 30, 1982, under the chairmanship of Carol B. Myers, Public Library of Charlotte and Mecklenburg County. In preparation for working on the state bibliographic database, this task force reviewed the "1980 Annual Report of Department of Cultural Resources, Division of the State Library, Information Services Section." Circulation figures, including InWATS/Interlibrary Loan, were examined, and the "North Carolina Union Catalog Policy Statement, January 1981" was reviewed.

The aim of the North Carolina Union Catalog was to be a complete record of the bibliographic resources of the libraries of the state. The catalog was housed at the State Library and microfilm editions were available to academic and public libraries. Directions to contributors included the directive that "children's books and light fiction should be omitted." However, "libraries with significant special collections are encouraged to report titles in this area." 24

The importance of a state database was recognized with OCLC as its basis. Questions were raised concerning the composition of such a database, including whether to use linked regional/local databases or one large database. What functions would this database perform-circulation, interlibrary loan, acquisitions? Who would maintain it? What benefits would a statewide database provide for library users?

Coordination with the other task forces was necessary as this group investigated what automation projects were currently in progress across the state. The pilot ZOCs were monitored, and automation activities in other states was explored.

In March 1983, two recommendations were presented to the Steering Committee: (1) to build on the core of MARC records that were already captured by North Carolina libraries belonging to OCLC; and (2) to provide alternative methods for non-OCLC users with non-OCLC records. Libraries were encouraged to contribute records for materials in all formats. Also, they were encouraged to do retrospective conversion of records giving priority to items of permanent value for research, items in special local or subject collections, and technical items not expected to be discarded as newer information became available. The use of the MARC format, OCLC Level I cataloging standards, and the second edition of the 
Anglo-American Cataloging Rules (AACR2) were established as standard. ${ }^{25}$ These recommendations were well received by the Steering Committee and the task force was asked to give specific recommendations for those libraries not currently automated.

Each member of the task force accepted responsibility for a segment of the topics being studied. In the July 1983 quarterly report to the Steering Committee, the task force presented a draft of a background paper aimed at librarians in any small library (school, public, or special) who had no funds for OCLC, but did have a microcomputer available. It included an introduction to US MARC, a statement of the necessity for following standards when cataloging, and recommendations for minimum cataloging. Options for libraries not currently automated were given. Five bases for automation comprised the options: a national bibliographic utility (OCLC), a vendor utility, a turnkey system, a microcomputer, or the state network. The task force also presented the option "to remain without automation until such time as a statewide system was identified and operable. Once such a statewide system was available the library would purchase any equipment necessary in order to access the state network and would incur only those fees connected with the use of the network." 26

Upon presentation of this background paper, the Task Force on Bibliographic Database requested confirmation of its direction from the Steering Committee. With the directions to include an analysis of vendor costs and a warning to use MARC-like tagging to be compatible with a larger system, the task force proceeded. In the 1982-83 Report to the State Library Commission, the Steering Committee praised the work of the Task Force on Bibliographic Database in the preparation of the paper on options for libraries and suggested that "a broader distribution of the entire document might be useful." 27

\section{Task Force on Document Delivery}

The Task Force on Document Delivery, chaired by Nell Waltner, North Carolina State University, identified two basic problems within lending institutions and between institutions. For successful transmission of interlibrary loan materials, there must be a financial commitment in a library for interlibrary loan (ILL) service, including staff and time. Several vendors were explored to identify a carrier service between institutions, including the U.S. Postal Service, United Parcel Service, Purolater, the State Courier Service, and facsimile transmission. The task force recommended building upon the delivery systems currently in existence rather than creating a new one. ${ }^{28}$ Since the State Library In-WATS line was not available to school libraries, the task force recommended that "the service could and should be extended to school libraries directly." 29

The second quarterly report, dated July 1983, reemphasized the need for libraries to provide the personnel needed to allow for a quick one-totwo-day turnaround of ILL requests, which should be available to all libraries - academic, special, public, and school. ${ }^{30}$ The Steering Committee continued support of the demonstration ZOC in planning for document delivery.

In the report to the quarterly meeting of the Steering Committee in September 1984, the Task Force on Document Delivery reported that the U.S. Postal Service and the United Parcel Service were being favored as carriers. ${ }^{31}$ In their final report the Western North Carolina Libraries ZOC did not address the document delivery issue. Their primary concern was the publication in a MARC format of the union list of periodicals of the 40 participating libraries. The Task Force devised a methodology for doing statistical studies on document delivery with programming and computer support provided by I. T. Littleton, North Carolina State University. ${ }^{32}$ 
By January 1986, the decision concerning the delivery of documents had not been resolved. Investigation continued on contracts with major package delivery companies within the state. The State Courier System and the U.S. Postal Service were rejected "because of spotty service patterns and the need to protect the items being delivered from damage." 33 Delivery systems in Pennsylvania and in Colorado were examined, with the recommendation from the task force to use Western Union's Easy-Link service that was being used in Colorado by the Department of Public Instruction to provide all schools and libraries within the state access to database vendors and bulletin boards as well as electronic mail.

\section{Task Force on Public Information}

The charge to the Task Force on Public Information was to develop a promotional strategy for the state library network to communicate the results of the King Research report and progress of the Steering Committee and task forces to librarians, trustees, friends, and government officials across the state. ${ }^{34}$ The chairman for 1982-83 was Patsy Hansel, Cumberland County Public Library and Information Center, with Carol Lewis, State Department of Public Instruction, succeeding Hansel in 1984.

Early in 1983 the task force began the design of a brochure about the network, which would explain the purpose of networking, what and who would be involved, and what was being done. The completed brochure was available for distribution at professional meetings in the fall of 1983.

A static display was designed to explain the purpose of the North Carolina Networking Steering Committee and to feature the two pilot ZOCs. The display was used at spring 1984 meetings of the North Carolina Community College Learning Resources Association and the North Carolina Educational Media Association as well as at the meetings of the NCLA Public Library Trustees Association at the 1983 NCLA biennial conference and the May 1984 meeting. The summer 1984 issue of North Carolina Libraries focused on networking projects in the state.

At the fall regional meetings of school/library media personnel, a questionnaire was distributed to high school media coordinators. The purpose of this survey was to determine the degree to which school media professionals "felt a need to become involved in networking" and "used networking strategies to provide resources to teachers and students." ${ }^{35}$ During the quarterly meeting in March 1985, the following results of the survey were disclosed: (1) most school library media specialists felt that they could fill student requests satisfactorily and most faculty requests; (2) there was a lack of awareness of network capabilities; and (3) microcomputers were used mainly for teaching computer literacy skills, yet were often placed near the media centers. ${ }^{36}$ The need to continue providing information about the potential of networking was expressed by the task force.

In an effort to publicize the contributions of libraries in the state, an Advisory Committee for the North Carolina Department of Cultural Resources, Division of State Library, under the chairmanship of Edward G. Holley, University of North Carolina at Chapel Hill, prepared and distributed a booklet "North Carolina's Libraries-Their Role: Statements of Mission and Purpose." This document was designed for the citizens of the state-businessmen, legislators, educators, and the general public. The purpose of the brochure was to explain the missions of various types of libraries-public, school, academic, special—with the expressed desire that the information provided would "lead to a better understanding of the vital roles libraries play in our educational, economic, and cultural life and that it will result in the public support necessary for their continued improvement." ${ }^{37}$ 


\section{Task Force on Funding}

Although funding may have appeared to be a primary concern, the Task Force on Funding felt it could not proceed very far until what was to be funded was determined. Their charges included investigating group discounts on equipment and services and developing a funding strategy for the network.

In their first meeting in December 1982, under the chairmanship of George Viele, Greensboro Public Library, the task force formed a plan of action to develop a funding manual covering basic information and basic minimum costs; to examine financial benefits to be derived from collective network activities such as group discounts for services, equipment, and software; and, finally, to create the building blocks of a funding strategy for a statewide library network. ${ }^{38}$

A nine-page manual was presented to the Steering Committee in October 1983. Sources of funds listed were divided into federal, state, and other categories. Federal funds were available from the Library Services and Construction Act (LSCA) and General Revenue Sharing Grants. The recommendation concerning state funding was to "seek special legislation to fund pilot multi-type library projects. These projects fit nicely into the pork-barrel legislation generally passed in the last day or two of each General Assembly session." 39 Other suggested sources of funding included the use of professional fundraising organizations, ZOC fundraisings, ZOC foundations, and a Multitype Library Credit Union.

In a letter to Marjorie Lindsey, Consultant for Multitype Library Cooperation, State Library, Viele stated, "The ultimate success of the Multi-Type Cooperation will depend on the voluntary cooperation of different types of libraries and their ability to achieve local funding. It is difficult to visualize a state network becoming a reality from the top down. I sincerely believe that the bottoms-up approach as proposed by Carol Myers' task force [on a bibliographic database] is the right one." ${ }^{40}$ At that time, the committee was also investigating the cost of using OCLC/SOLINET.

The Task Force on Funding presented another report at the September 1984 meeting of the Steering Committee in which it made further suggestions in the search for funding. Industrial and business contributions were considered, especially for purchase of hardware. "Business and industry may be especially interested if the network provides information resource needed for industrial research. Businesses and industries also have an interest in excellent public library resources for their staffs as a part of the educational resources of the state." 41 A state legislative appropriation was identified as the best possibility for permanent funding of an on-going network; however, it would need to be built into the state continuation budget.

\section{Task Force on Technology}

The task of investigating the technology available in a rapidly advancing field was a difficult one. Chairperson for the first two years was Libby Smith, Environmental Protection Agency, who as part of her duties also served on the Governor's Task Force on Science and Technology. At its first meeting the task force defined several aspects which it needed to address, including the monographic file, the serials file, an audiovisuals file, telecommunications, and integrated library automation systems (ILAS) at the individual library or ZOC levels. Reports in the literature were gathered and on-site visits were made to libraries that were developing systems using computers. Sheppard Memorial Library in Greenville was using word processing and a database management system as well as providing online reference service via DIALOG. Several libraries were considering automated 
circulation systems. Vendors providing electronic mail were explored. The applicability of SOLINET's LAMBDA Project and the Triangle Research Library Network as bases to enhance access provided by OCLC were investigated. ${ }^{42}$

A review of SOLINET and the North Carolina Union List of Serials comprised its study during 1983. The deregulation of American Telephone $\&$ Telegraph (AT\&T) caused a delay in an investigation of telecommunications vendors. In the year-end report of the Task Force on Technology, it was recognized that North Carolina libraries would prefer to select systems with features appealing to their situations, resulting in a variety of systems being installed across the state, making a standard state system "out of the question." 43 For a central statewide catalog a statewide list of serials, the use of SOLINET'S LAMBDA automated library system was preferred. The Western North Carolina Library Association's ZOC was proceeding using LAMBDA.

The charges going into the second biennium of the Task Force on Technology continued the work of the first task force, with William A. Gosling, Duke University, serving as chairman. The ZOCs were monitored from a technology perspective. Telecommunications possibilities included WATS lines, microwave, satellite, and existing organizations such as the North Carolina Agency for Public Telecommunications and the North Carolina Educational Computing Service with LINC-NET. A survey of current library automation within the state was proposed in conjunction with MUGLNC, the Microcomputer Users Group for Libraries in North Carolina. MicroNet, the network that linked area schools and Western Carolina University, was investigated. Initiated in September 1982, MicroNet provided "access to information to teachers and students throughout North Carolina, allowing them to interact with their peers through a computer network, plus provide a vehicle for offering instructional programs while removing the traditional time and logistical constraints." 44

The committee also reviewed the March 5, 1983 draft of a paper entitled "Establishment of a State-wide Communication System Among the North Carolina School Systems." The Division of Educational Media and Technology Services of the North Carolina Department of Public Instruction proposed the idea of developing a statewide communication system among the North Carolina school systems. It included a state plan to establish a philosophical base for the acquisition and utilization of computers for both administrative and instructional purposes in the schools of North Carolina. Three phases were proposed to occur over a three-year period: (1) an assessment of current uses of computers; (2) installation of minicomputers in pilot sites; and (3) using pilot projects as test groups. Components of the proposed statewide system were electronic mail, electronic conference, bulletin boards, and online databases of resources persons across the state, computer assisted instruction software, and applications of technology. 45

In the quarterly report to the Steering Committee, the task force wrote, "It was noted that many school libraries are unable to get approval from administrators to participate on a reciprocal basis. It may be that these libraries' access could develop through joint use of public libraries' services. It was suggested to Marjorie Lindsey that contact be made with the Deputy Director of Education to see what could be done from that source to build support for school libraries to participate more fully in such networks, including lending, sharing records and building administrators' support. Central processing centers might also provide the point of entry to the network." 46

By the end of 1985, the task force was to recommend a timeframe for a 
phased development of a statewide library network. Coordination with other task forces was a necessity. ${ }^{47}$ At the March 1985 meeting of the Networking Steering Committee, Gosling identified networking that was currently in place within the state: State Library interlibrary loan service network; health science libraries; public libraries; TRLN (Triangle Research Libraries Network); ZOCs; BIS, the online catalog for UNC-CH, DUKE, and NCSU; special libraries networks; and the OCLC interlibrary loan subsystem. He went on to identify the links that were needed: school to school, school to public, community colleges to Media Processing Center, public to public, public to academic, academic to academic, academic to non-academic, and the State Library to others. The task force outlined components of a North Carolina Information Network-interlibrary loan, union listing, e-mail, database services, and online document deliveryand emphasized the capability of OCLC to create the North Carolina bibliographic database. ${ }^{48}$

In May, the task force made the following recommendations to the Steering Committee: (1) to endorse serials listing project through OCLC; (2) to create a master database of all records for all libraries within the state by adopting the OCLC capability of forming a North Carolina bibliographic database, using state funds rather than individual library funds to cover startup costs; (3) upon adoption of recommendation 2, to secure from current OCLC members permission to allow inclusion of their records in a North Carolina database maintained at OCLC; (4) to identify libraries with significant collections to be encouraged to become early participants; (5) to recommend that the State Library Processing Center become a full SOLINET/OCLC member and that separate symbols for community college libraries be established. The recommendations report concluded with a cost comparison between the creation of a new complete bibliographic system within North Carolina versus use of the SOLINET/ OCLC system. ${ }^{49}$

\section{Task Force on Education and Training}

The Task Force on Education and Training was not one of the original task forces, but grew out of the State Library Continuing Education Study Advisory Committee formed in 1982 to oversee a statewide study of continuing library education. The study had resulted in a listing of library education programs and their providers entitled "Learning in Progress: A Study of Continuing Library Education in North Carolina."

This State Library advisory committee was reconstituted as the Task Force on Continuing Library Education Task Force, chaired by Jane Williams, State Library. Work of this group was independent of the networking studies although information was shared between the groups. In a report to the Steering Committee in January 1983, the task force presented three observations: (1) the need to break down electronic and psychological barriers in decision making by librarians as revealed in a study by Alan Samuels (UNC-Greensboro) and Charles McClure (University of Oklahoma); (2) the trend in the profession to specialization, resulting in little awareness of activities in other types of libraries; and (3) the recognition that although the term "zone of convenience" was new, the concept had been in effect with various cooperative arrangements. Three projects for the State Library were proposed: (1) the creation of a database of continuing education programs; (2) the creation of a database of individuals to conduct workshops; and (3) closer planning between continuing library education providers and participants. ${ }^{50}$

In July 1983, recognizing the needs for network-related training, the Education and Training Task Force was formed as a part of the Networking committees while the Continuing Library Education Task Force became a 
council for planning and coordinating. A Library Manager's Assessment and Development Seminar was also planned for July 1983. The target audience for this seminar was public library directors, school media supervisors, community college personnel, and State Department of Public Instruction personnel. Many of the intended audience voiced the opinion that public school librarians were seldom in management-level positions. Marjorie Lindsey of the State Library reacted differently by asking if SDPI personnel meant "only the managers in the State Department of Public Instruction and not practicing school librarians? ... I guess I'm wondering, if school librarians never get to be 'managers' what would be the point of including DPI people?"51

\section{Task Force on ZOCs}

The term "ZOC" first appeared in the King Research Report. In discussing networking configurations, consultants defined a ZOC as "a library or group of libraries that can conveniently share resources. The convenience can arise from a variety of factors including, but not limited to geographic proximity, similarities in types of patrons, dissimilarities in collections, existing cooperative relationship, special relationships among libraries or librarians." ${ }^{52}$ A library can belong to more than one ZOC, according to the services provided by a ZOC. ZOCs allow flexibility in establishing cooperation as well as building on the existing cooperative practices.

Under the leadership of Ruth Katz, East Carolina University, the Task Force on ZOCs examined the structure of existing cooperative library activities in the state, including organizational structure, financial structure, sources of funding, legal arrangements, and governance. Members of the task force formulated the guidelines for submitting requests for ZOC proposals to receive an LSCA grant, reviewed the proposals, awarded the grants, and monitored the progress of the ZOCs. One guideline was that two or more types of libraries were to be included "with school library participation seen as highly desirable." 53

\section{ZOC Projects}

\section{Western North Carolina ZOC}

The public, academic, and special libraries in the western section of the state had formed an association, the Western North Carolina Library Association. The main project of this association had been a union list of serials, the fourth edition being published in 1975. Plans had been made to update this list when the ZOC project grants were announced. The ZOC proposal to update the union list was accepted in October 1983. The project director at the time of the grant was Shirley McLaughlin, Asheville-Buncombe Technical College.

The Western North Carolina ZOC project involved forty libraries in twenty-three counties, serving a population of over 615,000 . Through a contract with SOLINET, they produced a union list from the holdings lists in a variety of formats submitted by the participating libraries. The fifth edition of the Union List of Periodicals in Western North Carolina was distributed in microfiche format. One hard copy laser-printed edition was on file as a master. Printed copies were for sale to other libraries. The Western North Carolina Association ZOC expressed its commitment to upgrading the quality of their serials records using MARC format. ${ }^{54}$

\section{Project CLONE}

Cooperative Libraries of Nash and Edgecombe Counties (CLONE) involves two technical colleges (Edgecombe Technical College, Nash County Technical College), two public libraries (Braswell Memorial Library, Edgecombe County Memorial Library), and a private college (North Carolina Wesleyan College). In a contract with a commercial vendor, 
CLONE produced a microfiche union catalog of over 166,000. High schools in the zone of cooperation also received copies. Olivia Weeks, Edgecombe Technical College, served as Project Director. ${ }^{55}$

\section{CLEVE-NET}

A history of cooperation and reciprocal borrowing through use of a common library card for the libraries in Cleveland County provided the foundation for their ZOC project. CLEVE-NET links two public libraries (Cleveland County Memorial Library, Mauney Memorial Library), a technical college (Cleveland Technical College)), four high schools (Burns High School, Crest High School, Kings Mountain High School, Shelby High School), and a private college (Gardner-Webb College). Under the direction of Douglass Perry, Cleveland County Memorial Library, CLEVE-NET completed two projects: (1) an online union list of patrons; and (2) a union list of Serials, accessible both in print format and online. A third project, which remained in the information-gathering stage, was to create an online local information file of community agencies and organizations. Electronic mail service provides a forum for resource sharing opportunities and personal contact among the librarians. Public events, college programs, and school activities are posted on an electronic bulletin board. ${ }^{56}$

\section{Wilson County Library Network}

After overcoming the technical difficulties of linking a variety of brands of microcomputers, the Wilson County Library Network began operation in the fall of 1985, under the direction of Peter A. Bileckyj, Wilson County Public Library. Other organizational members included two academic libraries (Atlantic Christian College-now Barton College, Wilson County Technical College), three high schools (Fike High School, Hunt High School, Beddingfield High School), a hospital library (Wilson Memorial Hospital), and the Eastern North Carolina School for the Deaf. The interactive electronic mail/bulletin board system was used to transmit interlibrary loan requests, reference requests, and professional information among member libraries. Projects being developed included a union list of serials, audiovisuals, and patrons.

\section{Health Sciences Union List of Serials}

Another ZOC grant was awarded to the health sciences libraries throughout North Carolina. This ZOC developed a Union List of Serials of Health Sciences Libraries.

The various task forces presented their final findings and recommendations to the North Carolina Library Networking Steering Committee in June 1985. The task forces and the Steering Committee ceased functioning and the North Carolina Networking Committee was formed, with Howard F. McGinn, then State Librarian, as the chair.

The implementation phase began with the formation of objectives and guiding principles that were approved by the Secretary of the Department of Cultural Resources Patric Dorsey, upon the recommendation of the State Library Commission. The Objectives and Guiding Principles of the North Carolina Information Network were printed in the January/February 1986 issue of Tar Heel Libraries: "The North Carolina Library Network exists to serve all the citizens of the state. Its sole purpose is the improvement of the daily lives of North Carolinians through the provision of information. It assumes that access to the information necessary to conduct our daily lives is a basic human right and that the facilitation of this access is a duty of government." 57

Local or regional programs, micronetting, will continue to be developed. Statewide programs, macronetworking, will concentrate initially on three projects: (1) the North Carolina Bibliographic Database, using the 
records in OCLC as a nucleus with records of tapeloading libraries added as available; (2) the North Carolina Union List of Serials, using the Western North Carolina Union List of Serials as a basis and the Health Sciences Union List of serials being added; and (3) the North Carolina library electronic mail/bulletin board system through a contract with a major statewide or national system.

The implementation date for the first of these projects, the North Carolina Bibliographic Database was June $1985 .{ }^{58}$ At

The NCIN provided the vision for the movement toward providing online services for all citizens of North Carolina. that point, test sites were being selected with OCLC members given preference, the training of trainers was being planned, information was still being collected for the Union List of Serials phase, and work was proceeding on securing a contract for the bulletin board/electronic mail portion of the network. The North Carolina Library Network entered into the implementation phase on October 25, 1985. Soon it would be known as the North Carolina Information Network (NCIN). The philosophy driving the further development and enhancement of the NCIN since 1985 has been for local libraries to identify their needs, plan cooperatively, and utilize the experiences gained by the ZOC

projects for technical assistance. This philosophy of local participation still exists in that it is the responsibility of local organizations to implement participation in the North Carolina Library Network.

In early 1992, a publication of the State Library of North Carolina listed the full range of member services to all libraries participating in the North Carolina Information Network:

- access to the North Carolina Online Union Catalog, North Carolina Union List of Serials, Interlibrary Loan, EPIC on OCLC as part of the North Carolina OCLC Group Access Capability (GAC)

- access to the SOLINET/SoLINE gateway to interlibrary loan in 10 Southeastern states

- access to AT\&T Easylink electronic mail and as well as North Carolina generated bulletin boards (to be phased out later in 1992)

- access to the University of North Carolina, Education Computing Service X.25 telecommunication lines, including LINC-Log Into North Carolina

- retrospective conversion of public library bibliographic holdings (LSCA, Title I)

- OCLC tape loading of multitype library MARC records into OCLC

- document delivery via telefacsimile. ${ }^{59}$

With the North Carolina Information Network now fully implemented, the stage was set for the development of the online statewide computer network, NC LIVE (North Carolina Libraries and Virtual Education) in the late 1990s, to be partially funded by the General Assembly of North Carolina. The NCIN provided the vision for the movement toward providing online services for all citizens of North Carolina.

This is but one portion of the story of the use of technology in North Carolina libraries to provide better service. Please view this effort as an invitation not only for further research on similar topics, but also for greater documentation, including archival collection development and oral histories of those involved in this ongoing transformation. Librarians expend a great deal of energy preserving others' stories; let us preserve a bit of our own. ${ }^{60}$

\section{References:}

The files of the North Carolina Network Steering Committee, including 
those of each task force, are available at the State Library of North Carolina. Folders of each task force as well as of the Steering Committee had been carefully collected by Marjorie Lindsey, Consultant for Multitype Library Cooperation at the State Library.

1 Jones, Plummer Alston, Jr., "North Carolina Networks: A Bibliography on Library Cooperation Involving the Old North State," North Carolina Libraries 50 (Special Edition 1992): 32-36.

2 Robert B. Downs, ed., Resources of North Carolina Libraries (Raleigh: Governor's Commission on Library Resources, 1965), 1.

3 Ibid., 3-4, 6-8.

4 Ibid., 32.

5 Ibid., 153.

6 Ibid., 154.

7 Ibid., 227, 229.

8 The Next Step for North Carolina Libraries: A Library Services Network; The Report of a Feasibility Study of the North Carolina Library Services Network (Raleigh: North Carolina State Library, North Carolina Library Association, State Board of Education, State Board of Higher Education, 1971), 4.

9 Ibid., 7.

10 Ibid.

11 Ibid., 3.

12 Summary of The Next Step for North Carolina Libraries (Raleigh: North Carolina State Library, 1971), 2.

13 Next Step, 8.

14 Ibid.

15 Alberta Smith, Access to Information for North Carolinians, Multitype Library Cooperation Working Paper No. 1, by Alberta Smith for Ad Hoc Committee on Multitype Library Cooperation and North Carolina Library Association Networking Committee (Raleigh: Division of State Library, North Carolina Department of Cultural Resources, 1981), 2.

16 Ibid., 2-3.

17 Ibid., 6.

18 Ibid., 8.

19 Ibid., 37.

20 Jose-Marie Griffiths and Donald W. King, North Carolina Networking

Feasibility Study (Rockville, MD: King Research, Inc., 1982), 1-2.

21 Ibid., 8.

22 Ibid., 132-34.

23 North Carolina Library Networking Steering Committee, "1982-83

Report to the State Library Commission," November 1983, 1.

24 "North Carolina Union Catalog Policy Statement," January 1981.

25 Task Force on Bibliographic Database, "Report to Steering Committee," March 1983.

26 "Some Options for Libraries Currently Not Automated," Draft, July

$13,1983,3$.

27 North Carolina Library Networking Steering Committee, "1982-83

Report to the State Library Commission," 1.

28 Task Force on Document Delivery, "Quarterly Report, April 1983," 4.

29 Ibid., 3.

30 Task Force on Document Delivery, “Quarterly Report, July 1983," 1.

31 Task Force on Document Delivery, "Quarterly Report, September 11, $1984, " 12$.

32 1983-85 North Carolina Library Networking Steering Committee and 1985-86 North Carolina Library Networking Committee, "Minutes, October 29, 1985," 1 .

33 "The North Carolina Library Network," January 14, 1986, 4.

34 "Task Force on Public Information, Charges-1982-84," 1. 
35 Memorandum, Carol Lewis to Steering Committee, March 12, 1985.

36 North Carolina Library Networking Steering Committee, "Minutes of Quarterly Meeting, March 12, 1985."

37 North Carolina's Libraries: Their Role-Statements of Mission and Purpose (Chapel Hill: UNC Press, 1983), endnote.

38 "Report to Steering Committee," December 9, 1982.

39 Task Force on Funding, "A Funding Manual for ZOCs of North Carolina."

40 Letter, George Viele to Marjorie Lindsey, October 25, 1983.

41 "Potential Sources of Funding for Statewide-Networking," presented September 11, 1984, at the Steering Committee meeting.

42 Task Force on Technology, "Quarterly Report," March 1983.

43 Task Force on Technology, "Final Report," October 1983.

44 Task Force on Technology. "Charges, 1984-85."

45 Establishment of a Statewide Communication System Among the North Carolina School Systems," draft, March 3, 1983.

46 Task Force on Technology, "Quarterly Report to North Carolina

Library Networking Steering Committee," January 24, 1984.

47 Task Force on Technology, "Charges, 1984-85."

48 North Carolina Networking Steering Committee, "Minutes of Quarterly Meeting," March 12, 1985.

49 Task Force on Technology, "Recommendations to the North Carolina Library Networking Steering Committee," May 16, 1985.

50 Task Force on Continuing Library Education, "Report to North Carolina Library Networking Steering Committee," January 1983.

51 Notes by Marjorie Lindsey on "Proposal for Library Managers' Assessment and Development Seminar, July 10-15, 1983."

52 King Report, 54.

53 Ruth M. Katz. "Zones of Cooperation: Aspects of Network Development," North Carolina Libraries 42 (Summer 1984): 58.

54 "Union List of Periodicals in Western North Carolina Libraries, Final Report - ZOC Project," June 1985, 25; Jones, "North Carolina Networks," 34-36.

55 Katz, 59; Jones, "North Carolina Networks," 34-36.

56 Interview, Diane Davies Kester with Douglas Perry, Shelby, NC, April

30, 1986; Jones, "North Carolina Networks," 34-36.

57 Tar Heel Libraries 9 (Jan./Feb. 1986): 2.

58 Ibid., 1.

59 "The North Carolina Information Network: A Service of the State Library of North Carolina, NC Department of Cultural Resources: Linking North Carolina to the World," draft 2/92, 2.

60 Our thanks to colleague, Kevin Cherry, past chair of the NCLA Round Table on Special Collections, who reminds us regularly of the importance of active documentation of library efforts, most recently as part of the "Hometown History" five-part workshop series sponsored by NC ECHO and the Federation of North Carolina Historical Societies in Spring 2002. 